\title{
EL PRÓlOGO DEL NUNCA MÁS Y LA TEORÍA DE LOS DOS DEMONIOS. REFLEXIONES SOBRE UNA REPRESENTACIÓN DE LA VIOLENCIA POLÍTICA EN LA ARGENTINA
}

\author{
EMILIO CRENZEL (CONICET / UBA) \\ Instituto de Investigaciones Gino Germani \\ Facultad de Ciencias Sociales \\ Universidad de Buenos Aires \\ Ciudad Autónoma de Buenos Aires, Argentina \\ ecrenzel@retina.ar
}

\section{Resumen:}

Este trabajo examina los procesos políticos que modelaron las claves interpretativas y narrativas del prólogo del informe Nunca Más. Este informe, elaborado por la Comisión Nacional sobre la Desaparición de Personas (CONADEP), creada en 1983 por el presidente constitucional Raúl Alfonsín para investigar el destino de los miles de desaparecidos causados por la represión estatal, se convirtió mediante diversos usos y resignificaciones en el canon interpretativo sobre la violencia política y la desaparición de personas en el país. Desde la publicación del informe, su prólogo ha sido especialmente discutido por su interpretación de la violencia política que atravesó a la Argentina. En estas páginas se examinarán los diversos procesos culturales y políticos, fruto de las iniciativas de diversos actores, que constituyeron las proposiciones del prólogo del Nunca Más y se presentarán ciertas certezas e indicios sobre su autoría. A partir de ello, propondré una perspectiva histórica sobre las premisas que condensa esta pieza emblemática en el campo de las interpretaciones sobre la violencia política que atravesó a la Argentina de los años setenta.

\section{Palabras clave:}

Nunca Más - Dos Demonios - Violencia Política - Argentina

\begin{abstract}
:
This paper presents a series of contributions to political thought processes that shaped the clubs and interpretive narratives Never Again foreword to the report This report, prepared by the National Commission on the Disappearance of Persons (CONADEP), created in 1983 by the constitutional president Raúl Alfonsín to investigate the fate of thousands of missing caused by state repression became, through various uses and new meanings in the interpretive canon of political violence and disappearances in the country. His preface is specially discussed by its interpretation of political violence that swept through Argentina. In these pages are the various cultural and political processes, the result of initiatives of various actors, which formed the prologue propositions Never Again and presented and the available evidence and certainty about its authorship. From this, I propose a historical perspective on the premises that condenses this iconic piece in the field of interpretations on the political violence that swept through Argentina in the seventies.
\end{abstract}

\section{Keywords:}

Never Again - Two Devils - Political Violence - Argentina 


\title{
EL PRÓlOgO DEL NUNCA MÁS Y LA TEORÍA DE LOS DOS DEMONIOS. REFLEXIONES SOBRE UNA REPRESENTACIÓN DE LA VIOLENCIA POLÍTICA EN LA ARGENTINA ${ }^{1}$
}

\author{
EMILIO CRENZEL (CONICET / UBA)
}

ecrenzel@,retina.ar

\section{Introducción}

En octubre de 2012 el informe Nunca Más, elaborado por la Comisión Nacional sobre la Desaparición de Personas (CONADEP), creada en 1983 por el presidente Raúl Alfonsín para investigar el destino de los miles de desaparecidos causados por la represión estatal, se convirtió nuevamente en centro del debate público. En una nota titulada "Robar a los muertos" Magdalena Ruiz Guiñazú, periodista ex integrante de la CONADEP, criticó la sustracción de la firma de Ernesto Sábato del prólogo del Nunca Más en una nueva reedición publicada por EUDEBA, deploró la inclusión del nuevo prólogo de la Secretaria de Derechos Humanos agregado al informe en 2006 y reclamo del gobierno un Nunca Más para los crímenes de la organización parapolicial Triple A. Sustracción y adición, entendía, reflejaban la política de "apropiación de la memoria" de los gobiernos kirchneristas. ${ }^{2}$

Mientras EUDEBA le recordó a Ruiz Guiñazú que el prólogo nunca llevó firma, Mario Sábato, hijo del presidente de la CONADEP, inició una campaña pública para incluir, en próximas ediciones del informe, la firma de su padre en el prólogo. ${ }^{3}$

Este debate, inscripto en la confrontación con la política oficial de derechos humanos, evidenció una vez más la importancia simbólica y política del Nunca Más en la sociedad argentina. Como demostré en mi investigación, desde su publicación en 1984, diferentes gobiernos y grupos de la sociedad civil utilizaron al Nunca Más para exponer sus propias lecturas sobre la violencia política, las desapariciones y la dictadura. Mediante esas intervenciones, contribuyeron a reproducir el carácter canónico del Nunca Más y, simultáneamente, resignificaron su sentido al introducir sus interpretaciones sobre este pasado. ${ }^{4}$

En este artículo vuelvo a examinar el Nunca Más para analizar tres cuestiones novedosas. En primer lugar, trazo la genealogía de la interpretación de su prólogo. Específicamente, examino el uso de las metáforas del infierno y el demonio en las denuncias de las desapariciones y, retomando investigaciones previas, el curso que asumió la crítica a la violencia guerrillera y estatal

\footnotetext{
1 Agradezco los comentarios a una versión preliminar de este trabajo formulados en el "Encuentro Internacional Fecundidad de la memoria. Desafíos del presente a los usos del pasado en América Latina", realizado en el Centro de Estudios Avanzados de la Universidad Nacional de Córdoba entre el 14 y el 16 de noviembre de 2011 y los de José Fernández Vega.

2 Véase http://www.lanacion.com.ar/1521586-robar-a-los-muertos, consultado el 11 de marzo de 2013.

3 Véase http://www.lanacion.com.ar/1526056-pide-que-el-prologo-del-nunca-mas-lleve-la-firma-de-ernesto-sabato, Consultado el 11 de marzo de 2013. En una comunicación personal, añadió que le preocupaba, además, la omisión de los nombres de los integrantes de la CONADEP en la contratapa de la reedición del Nunca Más, incluidos en anteriores ediciones. Comunicación electrónica de Mario Sábato con el autor, 12 de noviembre de 2012.

${ }^{4}$ Para la historia de la elaboración, usos y resignificaciones del informe Nunca Más, véase Crenzel, Emilio, La historia política del Nunca Más. La memoria de las desapariciones en la Argentina, Buenos Aires, Siglo XXI, 2008.
} 
entre 1973 y 1983. En función de ello, muestro como estas metáforas y esta perspectiva sobre la violencia se inscribió en una nueva configuración memorial y política, mediante el enjuiciamiento de las cúpulas guerrilleras y las Juntas militares impulsado por el gobierno de Alfonsín y en el prólogo del Nunca Más. En segundo lugar, analizo el proceso de emblematización del Nunca Más y los principales debates que provocó su prólogo entre 1984 y 2012, inscribiéndolos en los contextos políticos que los enmarcaron. Por último, presento el proceso de elaboración del prólogo del Nunca Más enfocando las certezas e indicios sobre su autoría y proponiendo su vínculo con ciertos procesos políticos que modelaron sus claves interpretativas. El artículo ofrece, así, una perspectiva comprensiva de la gestación de la interpretación dominante sobre el proceso de violencia política que vivió el país cuarenta años atrás.

\section{La genealogía de una representación de la violencia política}

"Pienso que todos los aquí presentes coincidirán conmigo en que cada vez que a través de testimonios personales o de documentos tomamos contacto con la cuestión de los desaparecidos en la Argentina o en otros países sudamericanos, el sentimiento que se manifiesta casi de inmediato es el de lo diabólico. Desde luego, vivimos en una época en la que referirse al diablo parece cada vez más ingenuo o más tonto; y sin embargo, es imposible enfrentar el hecho de las desapariciones sin que algo en nosotros sienta la presencia de un elemento infrahumano, de una fuerza que parece venir de las profundidades, de esos abismos donde inevitablemente la imaginación termina por situar a todos aquellos que han desaparecido. Si las cosas parecen relativamente explicables en la superficie - los propósitos, los métodos y las consecuencias de las desapariciones -, queda, sin embargo, un trasfondo irreductible a toda razón, a toda justificación humana; y es entonces que el sentimiento de lo diabólico se abre paso como si por un momento hubiéramos vuelto a las vivencias medievales del bien y del mal, como si a pesar de todo lo demoníaco estuviera una vez más ahí diciéndonos ¿ves? existo: ahí tienes la prueba". ${ }^{5}$

El 28 de febrero de 1984, en su plenario semanal, los miembros de la CONADEP decidieron publicar estas palabras, redactadas por el escritor Julio Cortázar en 1981 para prologar las actas del "Coloquio de París", un encuentro donde abogados y militantes de derechos humanos discutieron estrategias para tipificar a las desapariciones como crimen de lesa humanidad, como homenaje al escritor días antes fallecido. ${ }^{6}$ El párrafo del prólogo, aquí transcripto, revela el uso por parte de Cortázar de las metáforas del infierno y del demonio para aludir el crimen de la desaparición. Pese a que a continuación Cortázar afirma la autoría humana de este crimen no dejará, en el resto de ese prólogo, de utilizar estas metáforas hasta caracterizar a la desaparición forzada como un círculo que le faltaba "al infierno dantesco".

Si bien en informes de organizaciones de derechos humanos obran antecedentes sobre el uso de la metáfora del infierno para caracterizar la represión estatal, por lo menos desde el ocaso de la dictadura de la "Revolución Argentina" (1966-1973), esta alegoría se volvió común durante la última dictadura militar (1976-1983) entre los denunciantes de las desapariciones. ${ }^{8} \mathrm{Su}$ instrumentalización abarcó a un conjunto vasto y diverso de actores quienes, al igual que Cortázar, no desconocían las características de las desapariciones ni la identidad de sus autores pero que, impactados por la naturaleza del crimen, buscaban resaltar su particular inhumanidad.

El uso de estas metáforas fue especialmente intenso entre los sobrevivientes de los centros clandestinos y una de sus primeras destinatarias fue una audiencia de singular importancia. El 12

\footnotetext{
${ }^{5}$ Cortázar, Julio, "Refus de l'oubli”, en Jouve, Edmond, Le refus de l'oubli. La politique de disparition forcée de personnes, París, Berger Levrault, 1982, págs.1-3.

${ }^{6}$ Comisión Nacional sobre la Desaparición de Personas (CONADEP), Nunca Más. Informe de la Comisión Nacional sobre la Desaparición de Personas, Buenos Aires, EUDEBA, 1984, acta 13, pág. 42.

${ }^{7}$ Cortázar, Julio, "Refus...”, op. cit., págs. 1-3.

8 Véase el informe del "Foro de Buenos Aires por la vigencia de los derechos humanos", 1973, págs. 1-5.
} 
de octubre de 1979, ante la Asamblea Nacional Francesa, al dar testimonio sobre su cautiverio en la Escuela de Mecánica de la Armada (ESMA), Ana Marti, María Milla de Pirles y Sara Solarz de Osatinsky, se presentaban como "sobrevivientes de un infierno, un horror dantesco", para luego describir con minuciosidad las características edilicias de la ESMA, y brindar nombres y apodos de represores y cautivos ilegales. ${ }^{9}$

También Robert Cox, editor del diario Buenos Aires Herald, desaparecido y luego exiliado afirmó, al comentar el libro testimonial de Jacobo Timerman, Preso sin nombre, celda sin número, publicado en 1980, que era "un testimonio veraz del infierno en el que habían convertido al país los militares". ${ }^{10}$ Ya en democracia, dos sobrevivientes del centro clandestino "La Perla", ubicado en la provincia de Córdoba, recordaban como un "infierno" su cautiverio. Desde entonces, otros sobrevivientes usaron esa metáfora para caracterizar su pasaje por los centros clandestinos. ${ }^{11}$

Simultáneamente a las primeras denuncias de los ex cautivos clandestinos, otros actores recurrían a esta metáfora. El grupo de Rock "Serú Girán", en su disco de 1980, "Bicicleta", incluía el tema "Encuentro con el Diablo" aludiendo a su reunión con el dictador Eduardo Viola, en la casa de gobierno, quien los convocó para conocer sus pareceres sobre la actualidad nacional y, en las postrimerías de la dictadura, el escritor Osvaldo Soriano retrató a las desapariciones como un "descenso a los infiernos" al introducir el libro del periodista Carlos Gabetta Todos somos subversivos, de gran éxito editorial en 1983, el cual postulaba que la Doctrina de Seguridad Nacional que guió la persecución dictatorial definía de manera amplia y difusa al enemigo. ${ }^{12}$

Puede afirmarse, tras este recorrido que resume testimonios similares, que las metáforas del infierno y los demonios se constituyeron en una representación recurrente de quienes padecieron y denunciaron la desaparición para referirse al impacto y al hiato que significaron en sus vidas y retratar a sus autores.

El uso de este recurso puede pensarse como fruto de dos procesos simultáneos de inicios de los años ochenta del Siglo XX. Por un lado, la conformación de la Shoá como tropos global de la violencia extrema y las experiencias límite. Como señala Traverso, la metáfora del infierno adquirió un estatus singular para aludir a lo vivido bajo el genocidio nazi, retomando su papel en la cultura occidental y en el imaginario cristiano como recurso para representar aquello vivido como irrepresentable. ${ }^{13} \mathrm{El}$ infierno, afirma con igual sentido Wieviorka, fue "asumido como referencia paradigmática de la definición del mal, fue evocado por los supervivientes del genocidio, para superar las carencias de un lenguaje que no podía restituir con palabras la realidad de la experiencia vivida". ${ }^{4}$

Por otro lado, obedeció a la renovada presencia de la cultura de los derechos humanos a escala internacional, la cual fue constituyéndose en la clave de denuncia de los crímenes de Estado tras

\footnotetext{
${ }^{9}$ Comisión Argentina por los Derechos Humanos (CADHU), “Testimonios de los sobrevivientes del genocidio en la Argentina", Barcelona, CADHU, 1979, pág. 1.

10 Cox, David, En honor a la verdad. Memorias desde el exilio de Robert Cox, Buenos Aires, Colihue, 2002, pág. 150.

${ }^{11}$ Contepomi, Gustavo y Contepomi, Patricia, Sobrevivientes de La Perla, Córdoba, El Cid Editor, 1984, pág. 14. Para el uso de esta metáfora por otros ex cautivos ilegales, véase Buda, Blanca, Cuerpo I - Zona IV: (el infierno de Suarez Mason), Buenos Aires, Contrapunto, 1988; Actis, Munú; Aldini, Cristina; Gardella, Liliana; Tokar, Elisa y Lewin, Miriam, Ese infierno. Conversaciones de cinco mujeres sobrevivientes de la ESMA, Buenos Aires, Sudamericana, 2001, y Watts, Jorge, Memorias del infierno, Buenos Aires, Peña Lillo, 2009.

12 Soriano, en Gabetta, Carlos, Todos somos subversivos, Buenos Aires, Bruguera, 1983, pág. 5.

13 Traverso, Enzo, La historia desgarrada. Ensayo sobre Auschwitzy y los intelectuales, Barcelona, Herder, 2001, págs. 235238. Este autor advierte que "la alegoría del infierno parece olvidar dos aspectos esenciales: por una parte en la Divina Comedia como en toda la tradición cristiana, el infierno es un lugar de expiación, donde cada condenado es consciente de su culpa y puede encontrar una razón de su suerte; por otra, se trata de un lugar de sufrimiento y lamento, nunca de deshumanización".

14 Wieviorka, Annette, Déportation et génocide. Entre la mémoire et lóubli, París, Plon, 1992, pág. 180.
} 
el golpe de $1976 .{ }^{15}$ En el contexto dictatorial, y ante la necesidad imperiosa de concitar la empatía de audiencias amplias, la denuncia comenzó a sostenerse en un imperativo moral, basado en la común pertenencia a la especie humana, ante la experiencia límite. ${ }^{16}$ En este marco, se situaron en primer plano los sufrimientos corporales de las víctimas de la represión, cuya humanidad era resaltada mediante la restitución de sus datos identitarios básicos, la apelación a sus valores morales y a su "inocencia". Simultáneamente, las violencias de Estado fueron caracterizadas como fruto de una decisión irracional, amplia e indiscriminada y sus perpetradores descriptos como deshumanizados ejecutores del mal, ajenos a todo imperativo moral. En este esquema binario, la política fue desplazada a favor de la figura de la víctima, pura en sus ideales, cuyo cuerpo era avasallado por las personificaciones del mal absoluto, ajenas a la humanidad del hombre y a toda razón.

En paralelo, la condena simultánea a la violencia guerrillera y al "terrorismo de Estado" se expandió dentro y fuera del país. Este discurso reconocía antecedentes. Como mostró Franco, la continuidad de la lucha armada, por parte del Ejército Revolucionario del Pueblo y luego de Montoneros bajo los gobiernos peronistas (1973-1976) legitimados por amplias mayorías electorales y la represión estatal, legal e ilegal, modificó la consideración que, sobre la violencia política, sostenían los partidos socialista, comunista, la fracción alfonsinista del radicalismo, grupos peronistas, y la izquierda maoísta y trotskista quienes la habían justificado o comprendido, aún como una metodología errada, como parte de la resistencia popular a la dictadura de la "Revolución Argentina". En ese marco, se constituyó una condena bipolar del "terrorismo de izquierda y de derecha" y de rechazo al "terrorismo de cualquier signo". ${ }^{17}$ Las firmas de Alfonsín y de Sábato rubricaban solicitadas públicas con este mensaje que evidenciaba la polarización política que atravesaba el país. Por supuesto, sin reconocer el ejercicio propio de la violencia como terror, este esquema era compartido por la guerrilla y las Fuerzas Armadas que se reconocían como contendientes en una guerra en la que no había neutralidad posible.

Tras el golpe de Estado de 1976, la dictadura prolongó, en paralelo a la demonización de la subversión, la condena de ambos "terrorismos". De hecho, prometió combatir por igual al terrorismo de izquierda y de derecha, a fin de restaurar el orden y recuperar el monopolio estatal de la fuerza. Cuando Rodolfo Walsh, militante montonero, denunciaba en su "Carta Abierta a la Junta militar" que "la Junta que ustedes presiden no es el fiel de la balanza entre "violencias de distintos signos" ni el árbitro justo entre "dos terrorismos" sino la fuente misma del terror" discutía la equidistancia discursiva enarbolada por la dictadura y, especialmente, las expectativas que logró sembrar en los actores y grupos que sostenían esa doble condena entre 1973 y 1976 varios de los cuales apoyaron, entusiastamente, el golpe de Estado. ${ }^{18}$ Luego del golpe, el rechazo de ambos terrorismos fue sostenido por ciertos organismos de derechos humanos, en especial la Asamblea Permanente por los Derechos Humanos, la Liga Argentina por los Derechos del Hombre y el Servicio de Paz y Justicia (que hacía del rechazo a la violencia su principal bandera)..$^{19}$ La equidistancia del "terrorismo de izquierda" y el "terrorismo de Estado", como preámbulo para denunciar los crímenes de Estado, fue enarbolada en sus informes por Amnistía

15 Sikkink, Kathryn, "The Emergence, Evolution, and Effectiveness of the Latin American Human Rights Network", en Hershberg, Eric y Jelin, Elizabeth (eds.), Constructing Democracy: Human Rights, Citizenship and Society in Latin America, Boulder, Westview Press, 1996, págs. 59-84.

${ }_{16}$ Markarian, Vania, Left in Transformation: Uruguayan Exiles and the Latin American Human Rights Networks, 1967-1984, Nueva York, Routledge, 2005, págs. 104-105.

17 Franco, Marina, "La "teoría de los dos demonios": consideraciones en torno a un imaginario histórico y a las memorias de la violencia en la sociedad argentina actual.”, en ;Atención!, Vol. 12, Instituto Austriaco para América Latina, Universidad de Viena, Austria, 2008, págs. 267-286.

18 Véase Walsh, Rodolfo, "Carta Abierta de un escritor a la Junta militar", en Operación Masacre, 14ava edición, Buenos Aires, Ediciones De la Flor, 1985 [1977], págs. 205-213.

${ }^{19}$ Sobre la adopción de esta perspectiva por los organismos, véase Veiga, Raúl, Las organizaciones de Derechos Humanos, Colección Biblioteca Política Argentina, nro 127, Buenos Aires, Centro Editor de América Latina, 1985, págs. 24-25 y págs. 113-115. 
Internacional y la Comisión Interamericana de Derechos Humanos de la Organización de Estados Americanos (CIDH), tras visitar el país en 1976 y 1979 para investigar las violaciones a los derechos humanos. ${ }^{20}$ En paralelo, como mostraron Rojkind y Jensen en sus investigaciones sobre el exilio argentino en México y Cataluña y Vezzetti en su trabajo sobre la cultura política revolucionaria, la crítica a los "dos terrorismos" fue asumida por militantes que revisaron en el exilio sus compromisos revolucionarios. ${ }^{21}$

Tras la derrota Argentina en la guerra de Malvinas en junio de 1982 Raúl Alfonsín, de la Unión Cívica Radical, anudó la metáfora del infierno con la crítica de la violencia política para retratar la historia argentina inmediata. Alfonsín afirmaba que "en el país se combatió al fuego con el fuego, a un demonio con otro demonio y, por ello, Argentina fue "un infierno". ${ }^{22}$ Ahora, metáfora infernal y explicación de la violencia se anudaban en una única proposición memorial y política.

En el discurso de Alfonsín la metáfora del infierno y la crítica de la violencia eran resignificadas. El infierno ya no remitía a la experiencia de los desaparecidos en los centros clandestinos ni el demonio sólo a los perpetradores de las desapariciones. Ahora, estas metáforas pretendían representar toda una época política y a sus protagonistas, que se proponía dejar atrás. Su crítica de la violencia, prolongaba su posición sostenida entre 1973 y 1976 y los preámbulos condenando a la guerrilla previos a la crítica del "terrorismo de Estado" durante la dictadura pero, ahora, adicionaba la idea de que la violencia guerrillera y estatal, por su común "elitismo epistémico", hicieron de la democracia y de la sociedad sus víctimas. Esta proposición encontraría un importante eco en un heterogéneo conglomerado de actores: amplios sectores que vivieron con miedo y ajenidad la violencia política, impugnadores políticos desde los años setenta de la violencia "de ambos signos", militantes e intelectuales que revisaron sus compromisos revolucionarios y quienes ahora tomaban distancia de la violencia al calor del clima democrático de 1983.

\section{La teoría de los dos demonios}

A tres meses de las elecciones presidenciales, Alfonsín precisó como se traduciría, en la justicia penal, su objetivo de que rindieran cuentas los perpetradores de las violaciones a los derechos humanos. Proponiéndose equidistante del "espíritu de venganza" y de la "voluntad de impunidad y olvido", aseveró que, si era elegido presidente, distinguiría a los autores materiales de la represión en tres categorías: "los que la planearon y emitieron las órdenes correspondientes; quienes actuaron más allá de las órdenes, movidos por crueldad, perversión, o codicia, y quienes las cumplieron estrictamente". Sólo quienes ordenaron los métodos ilegales y quienes se "excedieron" en el cumplimiento de las órdenes serían enjuiciados. El juicio y la sanción penal procurarían, mediante una sanción ejemplar, establecer la subordinación de los actores a la ley, prevenir nuevas violencias y consolidar la democracia. ${ }^{23}$

Pese a condenar en sus discursos la violencia guerrillera, Alfonsín no mencionó que también la enjuiciaría. Por su parte, el 23 de septiembre de 1983, a un mes de los comicios, la dictadura sancionó la ley 22.924 de "Pacificación Nacional" que declaraba "extinguidas las acciones penales

\footnotetext{
${ }^{20}$ Crenzel, Emilio, Génesis, usos y resignificaciones del Nunca Más: La memoria de las desapariciones en Argentina, Tesis de Doctorado en Ciencias Sociales, Facultad de Ciencias Sociales, Universidad de Buenos Aires, 2006, pág. 53.

21 Rojkind, Inés, "La revista controversia: reflexión y polémica entre los argentinos exiliados en México.", en Yankelevich, Pablo (Comp.) Represión y destierro. Itinerarios del exilio argentino, La Plata, Al Margen, 2004, págs. 223-251; Jensen, Silvina, Suspendidos de la historia/ exiliados de la memoria. El caso de los argentinos desterrados en Cataluña (1976-...), Tesis de Doctorado, Universidad Autónoma de Barcelona, 2004, págs. 851-878 y Vezzetti, Hugo, Sobre la violencia revolucionaria. Memorias y olvidos, Buenos Aires, Siglo XXI, 2009, págs. 117-118.

22 "Duras acusaciones de Alfonsín a los militares", $A B C, 7$ de julio de 1983, pág. 30.

23 Alfonsín, Raúl, Ahora, mi propuesta politica, Buenos Aires, Sudamericana-Planeta, 1983, págs. 142 y 148 y Nino, Carlos, Juicio al mal absoluto. Los fundamentos y la historia del juicio a las juntas del proceso, Buenos Aires, Emecé, 1997, págs. 106 y 230 .
} 
emergentes de los delitos cometidos con motivación o finalidad terrorista o subversiva desde el 25 de mayo de 1973 hasta el 17 de junio de 1982" y a "todos los hechos de naturaleza penal realizados en ocasión o con motivo del desarrollo de acciones dirigidas a prevenir, conjurar o poner fin a las referidas actividades terroristas o subversivas cualesquiera hubiera sido su naturaleza". La ley garantizaba la impunidad de las Fuerzas Armadas y, con salvedades importantes, de la guerrilla. ${ }^{24}$

En ese marco político, Alfonsín decidió que tanto "el terrorismo subversivo como el terrorismo de Estado" serían castigados. ${ }^{25}$ La simetría conjugaba tres objetivos. Primero, traducía su idea de que la anomia había originado la guerrilla y la represión ilegal. Sólo restaurando la ley era posible superarla. ${ }^{26}$ En este sentido, la nueva transición se diferenciaría de las políticas implementadas en 1973, cuando la amnistía se reveló ineficaz para detener la violencia política. Segundo, enfrentaba la "autoamnistía", sin que pudiese ser acusado de parcialidad por las Fuerzas Armadas. ${ }^{27}$ Por último, recogía la opinión favorable a castigar los crímenes de las Fuerzas Armadas, potenciado por su revelación diaria en la prensa, reclamo acompañado por una condena similar de la violencia guerrillera.

Esta idea, despojada de las metáforas infernales, se plasmaría en el lenguaje del derecho penal en los decretos 157 y 158 mediante los cuales Alfonsín, ya presidente, ordenó enjuiciar a siete jefes guerrilleros y a las tres primeras Juntas militares de la dictadura. ${ }^{28}$ Las cúpulas guerrilleras serían enjuiciadas por su actuación desde 1973 hasta 1983 mientras las Juntas militares por los actos cometidos en la represión del terrorismo tras el golpe de Estado de marzo de 1976. Así, condenaría a aquellos que desafiaron el monopolio estatal de la fuerza o, detentándolo, lo usaron ilegalmente. La condena de la violencia política diferenciaba la legalidad y la legitimidad de quienes la instrumentalizaron. La guerrilla se proponía como antecedente y causa de la represión estatal y, de hecho, sería el único actor acusado por la violencia previa al golpe, pero también sus acciones tras él serían juzgadas. En cambio, el examen de la metodología ilegal, que "impidió establecer culpabilidades e inocencias", usada por las Fuerzas Armadas para combatirla, se acotaría al período abierto tras el golpe de Estado de 1976, excluyendo su intervención bajo el gobierno constitucional de la viuda de Perón. De este modo, su presentación de la secuencia de la violencia política invertía la proposición del imaginario revolucionario que, una década antes, justificó la violencia popular como respuesta a la "violencia del sistema" y validaba la interpretación dictatorial que proponía que la represión estatal tuvo por objeto exclusivo combatir a la guerrilla pero se enfrentaba a esa perspectiva al establecer que vulneró, en miles de casos, los derechos elementales de la persona humana. ${ }^{29}$

Así, se limitaría a las cúpulas de dos actores la responsabilidad de la violencia política y se explicaría la violencia de Estado, aunque no sus procedimientos, por la violencia guerrillera, exculpando las responsabilidades políticas y morales de las corporaciones económicas, políticas y religiosas. La "sociedad" había sido víctima de ambas violencias, al igual que la democracia y la ley. Otro tanto lo eran los desaparecidos, en cuyo universo había terroristas, disidentes y personas encontradas en actitud no violenta sin precisarse proporciones entre estas categorías de víctimas. Los decretos exculpaban, además, a los seguidores de las cúpulas guerrilleras: "reclutados muchas veces entre una juventud ávida de justicia y carente de la vivencia de los medios que el sistema

\footnotetext{
${ }^{24}$ Ley de pacificación nacional, nro. 22.924, Boletín Oficial, 27 de septiembre de 1983.

${ }^{25}$ Nino, Carlos, Juicio al mal..., op. cit., pág.111.

${ }^{26}$ Osiel, Mark, "Ever Again: Legal Remembrance of Administrative Massacre," University of Pennsylvania Law Review, 144, 1995, págs. 478-489.

${ }^{27}$ Acuña, Carlos y Smulovitz, Catalina, "Militares en la transición argentina: del gobierno a la subordinación constitucional.", en Acuña, Carlos; Vaccheri, Adriana, et al., Juicio, castigos y memorias, Derechos Humanos y justicia en la política Argentina, Buenos Aires, Nueva Visión, 1995, págs. 51 y 52.

${ }^{28}$ Poder Ejecutivo Nacional, Decretos 157 y 158, Boletín Oficial, 15 de diciembre de 1983, págs. 4-5.

${ }^{29}$ Crenzel, Emilio, La historia política..., op. cit., págs. 57 y 58.
} 
democrático" y a los cuadros subalternos de las Fuerzas Armadas bajo el argumento de que su responsabilidad se veía "especialmente reducida" por la "acción psicológica" de la Doctrina de Seguridad Nacional "que bien pudo haberlos inducido, en muchos casos, a error sobre la significación moral y jurídica de sus actos dentro del esquema coercitivo a que estaban sometidos", idea que vertebraba la tesis oficial de que la obediencia debida y el contexto ideológico imperante eximían de responsabilidad penal a los oficiales y suboficiales de las Fuerzas Armadas. Así, los responsables penales de la violencia en la Argentina, serían sólo siete guerrilleros y los nueve miembros de las tres primeras Juntas militares. ${ }^{30}$ De este modo, la explicación de la violencia esgrimida durante la campaña electoral se transformó en una proposición jurídica. La novedad de la "teoría de los dos demonios" respecto de la crítica de la violencia desenvuelta entre 1973-1976, consistía en la postulación de un tercero diverso, conformado tanto por actores como por valores, como víctima de las cúpulas de dos actores responsables exclusivos del pasado de violencia. ${ }^{31}$

Pese a que, al parecer, los decretos se redactaron el 9 de diciembre, horas antes de que asumiera la presidencia, la frontera del enjuiciamiento que establecían era fruto de una intención meditada. Como recuerda Jaime Malamud Goti, uno de los arquitectos de la política de derechos humanos de Alfonsín, el gobierno decidió no extender las inculpaciones al peronismo, y al sindicalismo de derecha, entre otros actores, para evitar acusaciones cruzadas entre la clase política por sus responsabilidades en el ciclo de violencia y una alianza entre los sindicatos y las Fuerzas Armadas factores, ambos, que desbaratarían la apuesta por instituir la ley para tramitar el pasado de violencia. La democracia sería, entonces, la frontera que, en oposición a la dictadura, aseguraría su no repetición. ${ }^{32}$

\section{Infierno y demonios y violencia política en el Nunca Más}

La creación de la CONADEP, comisión que tenía por meta investigar el destino de los desaparecidos, integrada por personalidades de la sociedad civil, entre ellas Ernesto Sábato, miembros de los organismos de derechos humanos, diputados radicales y asesores del gobierno, supuso nuevas utilizaciones del esquema crítico de la violencia de izquierda y derecha y de las metáforas infernales.

La primera de ellas sucedió el 4 de julio de 1984, en el programa televisivo Nunca Más mediante el cual la CONADEP adelantó las conclusiones de su investigación. En su preámbulo, el Ministro del Interior, Antonio Tróccoli, sostuvo que el terrorismo subversivo antecedió a la violencia de Estado, a los que igualó por su "metodología aberrante" diluyendo, así, el status específico de la desaparición como crimen. Como corolario del programa, Sábato, presidente de la CONADEP, propuso que "la subversión que precedió al terrorismo de Estado" y caracterizó lo sucedido como "un crimen monstruoso, de lesa humanidad" y enfatizó que "esto no es un problema político, como se suele argüir, esto es un problema ético y religioso. Personalmente, creo que ha sido el reinado del demonio sobre la tierra". Estos "actos demoníacos", prosiguió, se cometieron "no ya contra los presuntos o reales culpables de algo, sino contra la inmensa mayoría de inocentes absolutos [...]". ${ }^{33}$

Así, mientras Tróccoli igualó a ambos terrorismos, Sábato prolongó el uso de la metáfora del infierno y el contraste entre la "pureza" de las víctimas y la figura demoníaca de los perpetradores, utilizadas en las denuncias de los crímenes durante la dictadura. Los organismos de derechos humanos criticaron a Tróccoli por su igualación de ambas violencias y resaltaron el papel de Sábato

\footnotetext{
30 Poder Ejecutivo Nacional, Decretos 157 y 158, Boletín Oficial, 15 de diciembre de 1983, págs. 4-5.

${ }^{31}$ Crenzel, Emilio, La bistoria política..., op. cit., pág. 58.

32 Verbitsky, 2003, pág. 38 y entrevista de Emilio Crenzel a Jaime Malamud Goti, Buenos Aires, 2 de Febrero de 2007.

${ }^{33}$ Discursos de Antonio Tróccoli y Ernesto Sábato en el programa Nunca Más.
} 
sin criticar la secuencia de la violencia que presentó, sus alusiones al demonio o su presentación de las víctimas. Incluso, solicitaron a la CONADEP copias del programa para difundirlo. ${ }^{34}$ Sólo Hebe de Bonafini, presidenta de Madres de Plaza de Mayo, criticó a Sábato por no mencionar que la mayoría de las víctimas "no eran ni niños ni adolescentes, sino hombres y mujeres que constituían la oposición política a la dictadura". 35

La segunda oportunidad en que las ideas y representaciones mencionadas se plasmaron por obra de la CONADEP fue cuando Sábato hizo entrega del informe al presidente Alfonsín, en la Casa Rosada, sede del gobierno argentino. En su discurso, Alfonsín, reiteró que en el país "se combatió al fuego con el fuego" y que por ello "la Argentina fue un infierno" mientras Sábato leyó pasajes del prólogo del informe y calificó a la represión como "demencial e indiscriminada".

La tercera ocasión, sucedió cuando la CONADEP publicó el Nunca Más. Su prólogo reproduce la secuencia de la violencia presente en los decretos 157 y 158 de juzgamiento a las cúpulas guerrilleras y a las Juntas militares que propuso a la violencia de estado como respuesta al "terrorismo", reduciendo la conflictividad en la sociedad argentina al enfrentamiento armado entre estos grupos. Sin embargo, se distancia de su igualación propuesta por Tróccoli en el programa de la CONADEP y de los decretos de juzgamiento que no las contrastaban cualitativamente, al remarcar la diferencia de naturaleza entre los "delitos de los terroristas" y "un terrorismo infinitamente peor que el combatido" que, ejercido por las Fuerzas Armadas desde el golpe, produjo un "crimen de lesa humanidad". Simultáneamente, el prólogo propone la ajenidad y la inocencia de "la sociedad" ante la violencia y retrata a los desaparecidos, como los denunciantes durante la dictadura, como un universo amplio e indiscriminado pero que, prácticamente, excluye a la guerrilla: "Todos, en su mayoría, inocentes de terrorismo o siquiera de pertenecer a los cuadros combatientes de la guerrilla". Así, reproduce la distinción entre inocentes y culpables (los terroristas) de los decretos de juzgamiento, pero introduce un criterio de proporcionalidad al interior del universo de las víctimas ausente en ellos. ${ }^{37}$ Así, el prólogo postula a "la sociedad", sus dirigentes y a los desaparecidos, como víctimas inocentes de la violencia estatal. ${ }^{38}$

El prólogo, además, retoma la metáfora del infierno y del diablo. Califica al sistema de desaparición como una "tecnología del infierno" pero, como las denuncias durante la dictadura, luego sostiene que el sadismo de los perpetradores no excluyó la regimentación de sus prácticas y subraya la responsabilidad orgánica de los altos mandos de las Fuerzas Armadas en el diseño del sistema criminal. $^{39}$ Con igual sentido, caracteriza como "caza de brujas o endemoniados" la persecución dictatorial a la cual califica de "demencial", fruto de un "delirio semántico" proponiendo, al igual que el decreto de juzgamiento de la Juntas militares, el carácter difuso de la frontera que, para las Fuerzas Armadas, comprendía la subversión y la "irracionalidad" que guió su persecución. ${ }^{40}$

Finalmente, la alegoría del infierno es usada para referir al universo de los centros clandestinos, las terribles violaciones que sufrieron allí los desaparecidos y la condición liminar de los sobrevivientes.

34 "Sábato enfrentó a Alfonsín. El shock de Nunca Más. "El eco militar”, Somos, 13 de julio de 1984, tapa y págs. 611; "Reacciones disímiles," Clarín, 6 de julio de 1984, pág. 6. Para la crítica de las Madres de Plaza de Mayo, véase "El ministro tuvo una actuación muy nefasta", La Voz, 6 de julio de 1984, pág. 4. Para las evaluaciones de Familiares de Detenidos y Desaparecidos por Razones Políticas y el SERPAJ, véase "Agradecen a Sábato por el programa Nunca Más.”, Tiempo Argentino, 18 de julio de 1984, pág. 6, y "Al hablar de la violencia no se puede ser simple, se debe ser claro,", Paz y Justicia, agosto de 1984, pág. 3. Sobre los pedidos del programa por parte de los organismos, véase Archivo de la CONADEP, actas de la CONADEP no. 33, 17 de julio de 1984, pág. 135, y no. 35, y 31 de julio de 1984, pág. 145 y Archivo de la APDH, Documentos C1, pág. 274 y C1, pág. 219.

35 "El ministro tuvo una actuación muy nefasta", La Vor, 6 de julio de 1984, pág. 4.

36 "Elogios de Alfonsín a la ciudadanía”, Clarín, 22 de septiembre de 1984, pág. 2, y "Desaparecidos: graves cargos se formulan en el informe Sábato”, Clarín, 21 de septiembre de 1984, págs. 2 y 3.

37 CONADEP, op. cit., págs. 9 y 10.

${ }^{38}$ Crenzel, Emilio, La historia política..., op. cit., págs. 105-110.

${ }^{39}$ CONADEP, op. cit., pág. 8.

40 CONADEP, op. cit., pág. 9. 
Así, el prólogo reproduce la leyenda del portal que, según la Divina Comedia de Dante, se encontraba en la entrada del infierno: "Abandonad toda esperanza, los que entráis" oficiando como metáfora del desamparo de los desaparecidos en los centros clandestinos; retrata como "suplicios infernales" la tortura que allí padecieron; y subraya la importancia de los testimonios de quienes "pudieron salir de ese infierno" en referencia a las declaraciones de los sobrevivientes que le permitieron a la CONADEP reconstruir el sistema de desaparición. ${ }^{41}$

El uso de estas metáforas en el prólogo se reproduce en el corpus del Nunca Más. La CONADEP retrata como "verdaderos infiernos" a los centros clandestinos, caracteriza como "descenso a los infiernos" a sus efectos en mujeres y niños, califica como "diabólica directiva" las desapariciones y como "prácticas diabólicas" la destrucción de los cuerpos de los desaparecidos asesinados pero, tras ello, explica los móviles racionales que impulsaban estas prácticas. ${ }^{42}$

El uso de estas metáforas fue interpretado como una "abstracción de las relaciones sociales e históricas" y de "reemplazo de esas fuerzas vivas, comprensibles, entramadas en una lucha política, por sujetos abstractos o no-humanos" paralela a la "angelización" de las víctimas fruto de la pluma de Sábato. ${ }^{43}$ Sin embargo, esta abstracción y la construcción de la figura de la "víctima inocente", reconocen una genealogía en las denuncias durante la dictadura; es relativa, ya que es usada retóricamente para luego ofrecerse una explicación racional y, por último, revela un uso compartido que trasciende a la CONADEP. En efecto, en el corpus del Nunca Más estas metáforas son enunciadas por los sobrevivientes en sus testimonios. Pedro Goin recuerda haber creído que "era la entrada al infierno" al arribar al "Pozo de Arana" en La Plata; Marta Candeloro afirma que "El infierno había comenzado" al narrar su paso por el centro clandestino la "Cueva", en la Base Aeronáutica de Mar del Plata; Eduardo Arias refiere a "aquél infierno" al relatar su cautiverio; Nelson Dean describe la tortura como un "marco diabólico" y Osvaldo Fraga afirma que vivió condiciones "infernales" en la Base Aérea de Morón. ${ }^{44}$

En síntesis, el Nunca Más propone una conjugación novedosa. Por un lado, reproduce en su prólogo la secuencia de la violencia entre los "dos terrorismos" y la idea de que la represión obedeció a la violencia guerrillera presente en los decretos de juzgamiento a las cúpulas guerrilleras y militares y, como su contracara, propone la inocencia de la sociedad y de las víctimas del "terrorismo de Estado". Por otra parte, establece la diferencia cualitativa entre el sistema estatal de desaparición y la violencia "terrorista" e identifica de forma exclusiva, mediante la alegoría del infierno y los demonios al crimen de Estado y a sus perpetradores. Quizás debido a estas tensiones su prólogo provocó lecturas disímiles.

\section{El prólogo del Nunca Más: debates y disputas políticas}

El Nunca Más se convirtió rápidamente en un éxito editorial, fue instrumento en los tribunales donde se dirimía, entonces, las responsabilidades en el pasado de violencia y su lectura se verificó en el plano de las representaciones sociales. La secuencia de la violencia postulada en su prólogo fue reproducida por el fiscal de Estado en su alegato final del juicio a las Juntas militares mientras, entre la opinión pública, diversas encuestas mostraban que un $90 \%$ de los consultados apoyaban la

condena de las Juntas pero valoraban positivamente, también, que se hubiese combatido a la subversión. La "teoría de los dos demonios" estaba en su cenit. ${ }^{45}$

\footnotetext{
${ }^{41}$ CONADEP, op. cit., págs. 9 y 10.

${ }^{42}$ CONADEP, op. cit., págs. 59, 246 y 317.

43 Drucaroff, Elsa, "Por algo fue. Análisis del Prólogo a Nunca más, de Ernesto Sábato.", en Tres Galgos, Vol. 3, Buenos Aires, 2002, pág. 25.

${ }^{44}$ CONADEP, op. cit., págs. 43-44, 151,173, 339.

45 Las encuestas de opinión fueron realizadas por la "Comisión Permanente en Defensa de la Educación” y la consultora Nudelman-Bass tras la sentencia del juicio a las Juntas, en diciembre de 1985, véase Galante, Diego, El
} 
Esta legitimación se reflejaría, también, en el exterior. La condena de la violencia de izquierda y derecha, localizada en el aristotélico justo medio ante los extremos, lugar por excelencia de la política, sería recurrentemente utilizada en las narrativas transicionales de la dictadura a la democracia y de la guerra a la paz en América latina. De hecho, varios informes de las "comisiones de la verdad" del continente, formadas para investigar las violaciones a los derechos humanos durante las guerras civiles, dictaduras y gobiernos autocráticos en la región, adoptaron esa premisa interpretativa. ${ }^{46}$

Sin embargo, la expansión del Nunca Más fue simultánea a la discusión sobre su interpretación. En diciembre de 1984, a sólo un mes de publicado, Osvaldo Bayer formuló una de las primeras críticas al prólogo. En su intervención en el "Coloquio de Maryland", un encuentro en una universidad de los Estados Unidos donde se debatió el rol de los intelectuales en la dictadura, reconoció que el argumento de los "dos terrorismos podía ser válido en el contexto del gobierno de Isabel Perón y de la represión ilegal de las Tres A" pero condenó la "teoría de los demonios" a la que identificó con la fórmula del repudio a la "violencia de cualquier signo" que circulaba en 1979 y que incluyó el informe de la CIDH y criticó a Sábato por su apoyo a las dictaduras de Onganía en 1966 y de Videla en 1976. ${ }^{47}$ En el país, Bayer acusó a Sábato de "colaboracionismo con la dictadura" y lamentó que el Nunca Más "adjudique al demonio el Holocausto argentino sin dar nombres" en alusión a la omisión en el informe de un anexo con la lista de responsables de las desapariciones identificados por la CONADEP. ${ }^{48}$

En el mismo momento, en el periódico de las Madres se afirmaba que el prólogo sugería que la represión respondió a la guerrilla cuando ésta ya estaba diezmada, ocultaba que el golpe buscó imponer el proyecto económico de las multinacionales y el imperialismo, y se enfatizaba que el informe buscaba "dar por muertos a los desaparecidos" y consagrar la impunidad. El prólogo recibió similar rechazo, por su presentación y "equiparación" de las violencias, del exilio político argentino en Barcelona. ${ }^{49}$

En contraposición con las críticas de Bayer y las Madres, el Centro de Estudios Legales y Sociales y la Liga Argentina de los Derechos Humanos lo valoraron como una pieza de acusación formidable contras las Juntas militares, pero también como un alegato que derrumbaba la estrategia jurídica oficial ya que demostraba la inexistencia de excesos y eliminaba el alegato de obediencia como causal de eximición de responsabilidades al proponer que todos los delitos fueron "atroces y aberrantes". ${ }^{0}$ Por su parte, los militares y sus aliados propusieron una crítica similar a la de las Madres pero de distinto signo. Cuestionaron el énfasis del prólogo en la violencia estatal y la equiparación que, entendían, proponía con la guerrilla. En diversas conmemoraciones, realizadas en

"Tuicio a las juntas militares". Derechos humanos, memoria y ciudadania en la Argentina (1983-2011), Tesis de Doctorado en Ciencias Sociales, Facultad de Ciencias Sociales, Universidad de Buenos Aires.

${ }^{46}$ Crenzel, Emilio, "Hacia una historia de la memoria de la violencia política y los desaparecidos en la Argentina", en Allier, Eugenia y Crenzel, Emilio (eds. y comps), Las luchas por la memoria en América Latina. Historia reciente y violencia política, México, 2013, en prensa. Para el uso de la "teoría de los dos demonios en Uruguay, véase Demasi, Carlos, "Un repaso a la teoría de los dos demonios", en Marchesi, Aldo; Markarian, Vania; Rico, Alvaro, y Yaffé, Jaime (Comps.), El presente de la dictadura. Estudios y reflexiones a 30 años del golpe de Estado en Uruguay, Montevideo, Trilce, 2004, págs. 67-74.

47 Bayer, Osvaldo, "Pequeño recordatorio para un país sin memoria", en Sosnowski, Saúl (Comp.), Represión y reconstrucción de una cultura: el caso argentino, Buenos Aires, EUDEBA, 1988, págs. 208-209.

48 “La verdad a medias, no", Diario de las Madres de Plaza de Mayo, año I, número 2, enero de 1985, pág. 5. y "Acerca del colaboracionismo de los intelectuales con la dictadura. La polémica Bayer-Sábato", "Carta de Sábato" y "Respuesta de Osvaldo Bayer", Diario de las Madres de Plaz̧a de Mayo, año I, número 4, marzo de 1985, págs. 6 y 17.

49 Véase "CONADEP Los desaparecidos no se archivan," Diario de las Madres de Plaza de Mayo, Diciembre de 1984, págs. 6 y 7 y Raquel Ángel, "Las trampas del Nunca Más," Diario de las Madres de Plaźa de Mayo, Enero de 1985, pág. 7. Para la evaluación del exilio argentino en Cataluña, véase Jensen, Silvina, "Suspendidos de la historia...”, op. cit., págs. 851-878.

50 Mignone, Emilio, "No hubo errores, no hubo excesos", Nueva Presencia, año VII, número 388, 7 de diciembre de 1984, pág. 7. 
cuarteles militares en aniversarios de ataques guerrilleros a esas dependencias, ocurridos bajo los gobiernos peronistas entre 1973-1976, resaltaron con vehemencia que su intervención fue ordenada por un gobierno constitucional y buscó preservar la democracia. Otros actores, mencionados en el Nunca Más, como el juez federal Rafael Sarmiento, pidieron la detención de Sábato y el secuestro de los ejemplares del informe. ${ }^{51}$

Las disputas continuaron un año después cuando la "teoría de los dos demonios" fue debatida en una serie de notas publicadas entre septiembre de 1985 y enero de 1986 en el semanario Nueva Presencia, activo denunciante de la dictadura. Sus protagonistas fueron intelectuales, periodistas y ex guerrilleros del E.R.P, algunos de ellos en condición de presos políticos cuya libertad los organismos de derechos humanos demandaban. Los organismos, consideran su existencia como una manifestación más de la equiparación de la guerrilla con el terrorismo de Estado y una posible moneda de cambio en una eventual amnistía a las Juntas militares. Los presos políticos, en un texto en el que admiten el error de continuar la lucha armada en 1973, confrontaron la teoría de los "dos terrorismos" con los testimonios recogidos en el Nunca Más los cuales, a su juicio, demostraban que los destinatarios del terrorismo de Estado excedieron a la guerrilla; destacaron que admitir la práctica de actos terroristas por la guerrilla no avalaba la "teoría de los dos demonios" que proponía una relación de causalidad entre la guerrilla, el terrorismo de derecha y el terrorismo de Estado pero, a diferencia de Bayer, identificaron en el discurso televisivo de Tróccoli al portavoz de esta teoría. $^{52}$

Finalmente, en 1989, el escritor y ex militante montonero Juan Gelman, al criticar los Indultos del presidente Menem, postuló que reproducían la simetría de los decretos de enjuiciamiento a guerrilleros y militares y consagraban la "teoría de los dos demonios" de Sábato. ${ }^{53}$

Sintéticamente, desde su publicación en 1984 hasta los Indultos, tanto el movimiento de derechos humanos como las Fuerzas Armadas criticaron la "teoría de los dos demonios" por equipar la violencia guerrillera y estatal. Estas críticas estuvieron vinculadas a sus diversas metas en los tribunales, objetando desde ángulos contrapuestos la política de justicia oficial, y buscaron consenso en la legitimidad que, entonces, ofrecía la democracia. Ciertos organismos como las Madres rechazaron de plano el prólogo y otros, como el Centro de Estudios Legales y Sociales, valoraron al Nunca Más por su condena al sistema clandestino sin criticar sus proposiciones sobre el pasado. Por último, quienes defendían o practicaron la lucha armada (Bayer, los presos políticos) admitieron la existencia de "dos terrorismos" o de "prácticas terroristas" entre 1973 y 1976, pese a desechar la "teoría de los dos demonios" que Bayer veía reflejada en el Nunca Más fruto de la pluma de Sábato, mientras los presos políticos consideraban que el informe de la CONADEP la refutaba al iluminar que el perfil de los desaparecidos trascendía a la guerrilla y al identificar a su portavoz en el ministro Tróccoli.

Las críticas al prólogo y su identificación regular con Sábato vehiculizaron el rechazo, desde posiciones opuestas, a las políticas de los gobiernos constitucionales: las Madres, Bayer y Gelman asociaron la "teoría" a la impunidad de los perpetradores y su autoría a un "colaborador de la dictadura", mientras las Fuerzas Armadas y sus aliados la enfrentaron evocando activamente la violencia subversiva y atacando al "autor" del Nunca Más y al informe en los tribunales.

Desde mediados de los años noventa del Siglo XX, en el contexto de la reproducción ampliada de la desigualdad social producida por las reformas neoliberales del presidente Menem y del creciente autoritarismo oficial, la noción de "terrorismo de Estado", impulsada por los

\footnotetext{
${ }^{51}$ Véase, como ejemplo, "Homenaje a los caídos en el batallón de Monte Chingolo”, Clarín, 22 de diciembre de 1984, pág. 8, y Westerkamp, Federico, "Fiel servidor del gobierno de turno”, La Razón, 23 de enero de 1985, pág. 11.

52 Anguita, Eduardo; Alberto Ces; Alberto Elizalde Leal; Arturo Vivanco; Carlos Brocato; Carlos Samojedny; Fernando Dondero; Hernán Invernizzi; Hernán Schiller; Ismael Viñas; José Cuesta; María Seoane; Pablo Seydell, y Roberto Bobrow, ¿Hubo dos terrorismos?, Buenos Aires, Editorial Reencuentro, 1986, págs. 30, 58-60, 67.

53 “La culminación de los dos demonios", Página/12, 11 de Octubre de 1989, pág. 6.
} 
organismos de derechos humanos, cobró presencia para caracterizar a la violencia dictatorial la cual fue asociada a la remodelación social y económica regresiva del país. Entonces, la discusión sobre el prólogo del Nunca Más se instaló en otro terreno. Por un lado, la reedición más importante del informe, publicada en fascículos en coautoría por EUDEBA y el diario Página/12, estuvo acompañada por los collages del artista plástico León Ferrari, cuya tradición es combinar la iconografía cristiana con motivos políticos y por su interpretación de que el cristianismo constituye la clave de las masacres y genocidios. En los collages, el infierno, ángeles y diablos solos o acompañando las fotos de los perpetradores de las desapariciones, ratifican sus interpretaciones sobre sus actos, la defensa de la civilización "Occidental y Cristiana" y los testimonios de los sobrevivientes que metaforizan con esa clave su cautiverio. Así, Ferrari propone al infierno como resultado y no como antítesis de la civilización occidental resignificando el sentido que, para el Nunca Más, tuvo la represión. ${ }^{54}$

Por otra parte, en 1999, EUDEBA reeditó el libro "El Estado terrorista argentino", de gran éxito editorial en 1983, escrito por Eduardo Luis Duhalde, abogado de extensa trayectoria en la defensa de presos políticos y denunciante de la dictadura en el exilio. La reedición presentó un apartado actualizado en el cual Duhalde criticó la "teoría de los dos demonios" por presentar una "simetría criminal" que "iguala un exterminio masivo con la violencia de un grupo de particulares", "oculta el conflicto político en una disputa metafísica" y considera "que el terrorismo de Estado tuvo por finalidad combatir al terrorismo cuando la guerrilla, al momento del golpe de 1976, estaba derrotada". Duhalde localiza la génesis de la teoría en los decretos de juzgamiento y afirma que el decreto 157 reproduce la Doctrina de Seguridad Nacional ya que "complementa" la persecución dictatorial al fundarse en que la represión ilegal impidió determinar inocencias y culpabilidades requiriéndose, por ello, establecerlas con el juicio de las cúpulas guerrilleras. Asimismo, mediante su crítica a las explicaciones metafísicas, alude veladamente al uso de las figuras demoníacas en el prólogo del Nunca Más. ${ }^{55}$

Así, su crítica a la "teoría de los dos demonios", centrada en los decretos de enjuiciamiento, anticipa el contenido del nuevo prólogo escrito bajo la administración de Néstor Kirchner, añadido por la Secretaría de Derechos Humanos de la Nación que Duhalde presidía, en el trigésimo aniversario del golpe. Éste, postuló que la CONADEP propuso una "simetría justificatoria" entre la violencia guerrillera y la estatal, al proponer que la violencia de Estado fue una respuesta a la guerrilla cuando ésta se encontraba derrotada proponiendo que el "terrorismo de Estado" se desencadenó, indiscriminadamente, para implantar un modelo económico excluyente. Incluso Rodolfo Mattarollo, entonces subsecretario de derechos humanos, afirmó que el prólogo expresaba una perspectiva similar al negacionismo de los crímenes nazis al postular a la "violencia de abajo" como antecedente del terror de Estado reproduciendo el argumento revisionista, en la "querella de los historiadores", que propuso al nazismo como respuesta a la Revolución Bolchevique. ${ }^{56}$ Así, desde mediados de los años noventa las intervenciones sobre la "teoría de los dos demonios" tuvieron una matriz diferente de sus predecesoras entre 1983 y 1990. Ahora, en un contexto signado por la impunidad de los violadores de los derechos humanos y la desigualdad creada por las políticas de "apertura económica y libre mercado" se visualizaba en la matriz de sentido del prólogo el sello de los perpetradores. El infierno era entendido como obra de la voluntad de dios y de los valores occidentales y cristianos; el juicio a guerrilleros y militares era

\footnotetext{
${ }^{54}$ Trabajé este tema en profundidad en Crenzel, Emilio, "El Nunca Más en fascículos: el infierno resignificado.", en Estudios Interdisciplinarios de América Latina y el Caribe, Volumen 17, 2, Instituto de Historia y Cultura de América Latina, Escuela de Historia, Facultad de Humanidades, Universidad de Tel Aviv, Israel 2006(b), págs. 87-106 y Crenzel, Emilio, La historia política..., op. cit., págs. 156-162.

${ }_{55}$ Duhalde, Eduardo Luis, El Estado terrorista argentino. Quince años después una mirada crítica, Buenos Aires, EUDEBA, 1999, págs. 167-178.

${ }^{56}$ Secretaría de Derechos Humanos de la Nación, pág. 8; Victoria Ginzberg, "De los dos demonios al terrorismo de Estado", Página/12, 15 de mayo de 2006, pág. 10. Para el argumento revisionista, véase Nolte, Ernest, La guerra civil europea 1917-1945: Nacionalsocialismo y Bolchevismo, Fondo de Cultura Económica, 2001 [1987].
} 
postulado como el complemento de la Doctrina de la Seguridad Nacional, y la "teoría de los dos demonios" como expresión del "negacionismo del genocidio".

\section{Autorías indocumentadas, sentidos compartidos}

La emblematización del Nunca Más estuvo regularmente asociada a la figura de Sábato. En el país, esta asociación se verificó en la frecuente denominación de la CONADEP como "comisión Sábato" y en la alusión al Nunca Más como "Informe Sábato". ${ }^{57}$ Lo mismo sucedió en el extranjero. La editorial finlandesa OTAVA Publishing Company y la danesa Lindhardt and Ringhof Publishers le solicitaron a la Editorial Universitaria de Buenos Aires (EUDEBA), que publicó el informe, los derechos para editar "la novela Nunca Más de Ernesto Sábato" y "el libro de Ernesto Sábato Non Camas". ${ }^{58}$ Aunque estos pedidos no prosperaron, la primera edición del Nunca Más publicada en el exterior, coeditada en 1985 por EUDEBA y la editorial española Seix Barral, incluía en su tapa una faja con la leyenda: "El llamado informe Sábato sobre los desaparecidos en la Argentina, un descenso a los infiernos" y la primera traducción del Nunca Más, publicada en portugués en 1985 por L\&PM Editores de Brasil, impulsada por grupos de familiares de brasileños desaparecidos en Argentina, aludía en su portada a Sábato como autor del Nunca Más.

Las críticas al Nunca Más, también estuvieron regularmente articuladas a la asociación entre su prólogo y la figura de Sábato corporizándose, así, en una persona distante de la izquierda y con una conducta por lo menos ambigua durante la dictadura. Sábato elogió al dictador Videla, tras reunirse con él en mayo de 1976, aunque adujo que en esa reunión pidió la liberación de un colega; acompañó la euforia nacionalista durante el Mundial de Fútbol en 1978 y la guerra de Malvinas en 1982, pero en 1981 presidió, junto a Adolfo Pérez Esquivel, Premio Nobel de la Paz, el "Movimiento para la Recuperación de Niños Desaparecidos". ${ }^{59}$ Como se dijo, dos figuras de peso en la izquierda y el movimiento de derechos humanos, Bayer y Gelman, habían criticado la "teoría de los dos demonios" asociándola a su pluma.

Ahora bien, como he explicado en otro trabajo, la escritura del Nunca Más fue una obra colectiva. Todos los comisionados de la CONADEP escribieron partes diversas del informe el cual, además, recibió los aportes de varias organizaciones de derechos humanos. El carácter colectivo de esta tarea se potenció cuando Sábato aclaró, en diversos plenarios de la CONADEP, que los capítulos del informe no llevarían firmas individuales como, de hecho, sucedió. ${ }^{60}$

La cuestión radica en que, como vimos, lo más discutido del Nunca Más ha sido la interpretación de su prólogo. Entonces, parecería central preguntarse quién o quiénes lo escribieron. ¿Fue realmente Sábato?, ¿Cómo funcionó en el caso del prólogo la autoría colectiva del Nunca Más?, ¿Hubo una reunión de la CONADEP en la cual se pensó y discutió su contenido? No es sencillo responder a estas preguntas, centrales para comprender las representaciones e ideas sobre la violencia política y las disputas sobre los derechos humanos.

Recordemos que el prólogo nunca estuvo firmado, como bien señaló EUDEBA ante la denuncia de Ruiz Guiñazú de que la firma de Sábato había sido omitida en una reedición del informe. La CONADEP asumió la autoría colectiva del Nunca Más en su conjunto. Según las actas de la CONADEP, Sábato presentó un proyecto de prólogo al plenario de la Comisión en agosto de 1984. No sabemos en qué consistía el proyecto en cuestión ni qué sucedió en esa reunión. Lo cierto es que a mediados de ese mes la CONADEP le encargó a Gerardo Taratuto - abogado y miembro de la secretaría de asuntos legales de la Comisión- que coordinase los aportes de los comisionados y unificara la redacción final del informe.

\footnotetext{
57 "Informe Sábato. Reclaman su publicación completa", Clarin, 5 de noviembre de 1984, pág. 6.

${ }^{58}$ Para los pedidos de las editoriales extranjeras, véase Archivo EUDEB A, Carpetas Nunca Más.

${ }^{59}$ Duhalde, Eduardo, El Estado terrorista..., op. cit., págs. 113 y 114 y Buenos Aires Herald, 13 de diciembre de 1981.

${ }^{60}$ Crenzel, Emilio, La historia política..., op. cit., pág. 94.
} 
Taratuto se convirtió, así, en una figura clave en la redacción del Nunca Más. Según su testimonio, Sábato le dijo que quería que el informe ofreciera una visión nacional, diera cuenta de la violación de derechos y principios fundamentales del orden político, moral y religioso, como el derecho a la vida, a la defensa y a la información, que la gente lo pudiese leer, lo entendiera hasta un ama de casa y que, si lo leía un militar, se avergonzara y no pudiera aducir que eran patrañas. ${ }^{61}$ Fue Taratuto quien organizó la secuencia expositiva del Nunca Más, reproduciendo las fases públicas (los secuestros) y clandestinas (torturas, cautiverio y asesinatos) de la desaparición forzada y tomó, según directivas de Sábato, a los testimonios de los familiares de los desaparecidos y de los sobrevivientes de los centros clandestinos como fuentes centrales del relato. ${ }^{62}$ Sin embargo, no queda claro cuál fue su intervención en la escritura del prólogo. Por un lado, siempre reservadamente, varios miembros de la CONADEP me afirmaron que Taratuto escribió la versión original. Sin embargo, el mismo negó que haya sido así en una entrevista personal que me concedió semanas antes de morir. "El prólogo es Sábato puro", dijo. Quizás había en ello un gesto de modesta renuncia y un reflejo de su admiración por el autor de "Sobre héroes y tumbas".

Como más de un miembro de la CONADEP recordó, nuevamente en forma reservada, Taratuto jocoso, al hablar de la cuestión, les había dicho: “¿Quién me creería si digo que el prólogo del Nunca Más no lo escribió Sábato y es obra de un tal Taratuto?". ${ }^{63}$ El interrogante no puede dirimirse con los documentos conservados por su familia. Tampoco, con los resguardados por la familia de Sábato y EUDEBA. ${ }^{64}$

Más allá de estas discrepancias entre los testimonios y de la ausencia de documentos, resulta indudable que Taratuto jugó un papel importante en la redacción del informe y, quizás, en la escritura del prólogo. No es menor que una personalidad con su trayectoria política haya tenido ese lugar. Gerardo Taratuto provenía de la izquierda. ${ }^{65} \mathrm{Ya}$ a fines de los años sesenta asumió la defensa de presos políticos y sindicales (como los militantes clasistas del Sitrac-Sitram) y en los años setenta de militantes guerrilleros como Roberto Quieto, dirigente de las Fuerzas Armadas Revolucionarias. Por su compromiso, su estudio jurídico fue blanco de dos atentados. Tenía, también, participación política. Integraba el maoísta Partido Comunista Revolucionario que reivindicaba la insurrección popular y rechazaba la guerrilla. En los años setenta su partido sostenía que "ambos terrorismos" estaban instigados por "dos imperialismos", el estadounidense y el soviético, reproduciendo el esquema maoísta sobre el escenario global a la realidad nacional. ${ }^{66}$ Tras el golpe de 1976, siguió ejerciendo la defensa de militantes, presentando hábeas corpus por personas desaparecidas hasta que marchó al exilio interno, a la localidad bonaerense de José C. Paz donde, en un pequeño estudió, continuó trabajando de abogado y desarrolló actividad teatral. A principios de los ochenta, participó en "Teatro Abierto", movimiento de resistencia a la dictadura. En 1983, adhería a la propuesta política de Alfonsín y fue convocado a la CONADEP a propuesta de Alberto Mansur, abogado peronista y secretario de Asuntos Legales de la Comisión. Es decir, una figura como la suya, crítico de la guerrilla pero que enfrentó a la represión estatal -antes y durante la dictadura

\footnotetext{
${ }^{61}$ Entrevista del autor con Gerardo Taratuto, Buenos Aires, 7 de diciembre de 2004 y Archivo de la CONADEP, actas de la CONADEP no. 36, 7 de agosto de 1984, pág. 147 y no. 38, 14 de agosto de 1984, págs. 156 y 157.

${ }^{62}$ Crenzel, Emilio, La bistoria política..., op. cit., pág. 95.

${ }^{63}$ Entrevista del autor con Gerardo Taratuto, Buenos Aires 7 de diciembre de 2004 y entrevistas del autor con varios comisionados de la CONADEP.

${ }^{64}$ Comunicación electrónica del autor con Juan Taratuto, 12 de marzo de 2013 y comunicación electrónica del autor con Mario Sábato, 12 de noviembre de 2012 y entrevista telefónica del autor con Mario Sábato, Buenos Aires, 13 de diciembre de 2012.

${ }^{65}$ Esta sección del artículo se basa en mi entrevista a Gerardo Taratuto, Buenos Aires, 7 de diciembre de 2004 y en las entrevistas que le realizaran a Taratuto Mauricio Chama, en Buenos Aires, el 12 de Diciembre de 1998 y Virginia Vecchioli, en Buenos Aires en 2002 a quienes agradezco haberme facilitado estas entrevistas.

66 Campione, Daniel, "La izquierda no armada en los años setenta: tres casos, 1973-1976", en Lida, Eugenia; Gutiérrez Crespo; Horacio, y Yankelevich, Pablo (Comps.), Argentina, 1976: Estudios en torno al golpe de Estado, Buenos Aires, Fondo de Cultura Económica, 2008, pág. 1.
} 
militar- estuvo de acuerdo, más allá del grado de intervención en la escritura, con la interpretación de los “dos demonios" presente en el prólogo.

Esta "teoría" no mereció discusiones. Los testimonios de los comisionados dieron cuenta de ello. Ninguno de los miembros de la CONADEP que entrevisté en mi investigación recordó que hubiesen existido debates sobre este tema. Tampoco se encuentra ningún registro de disidencia en las actas de la Comisión. ${ }^{67} \mathrm{Si}$ las hubo, probablemente se manifestaron verbalmente, aunque evidentemente se zanjaron al punto de que nadie pretendió sentarlas por escrito ni las mencionó varias décadas después, lejos de la coyuntura política en la que fueron silenciadas. Entonces, más allá de quien escribió el prólogo, Sábato, Taratuto y los otros miembros de la CONADEP acordaron en su contenido en este punto en el que coincidieron representantes del gobierno de Alfonsín, representantes de fracciones importantes el movimiento de derechos humanos y personas con trayectorias de izquierda, más allá de sus diferentes posiciones políticas y sus disímiles compromisos ante la dictadura.

Sin embargo, resulta necesario advertir que otros párrafos del prólogo remiten a interpretaciones que no parecerían fáciles de ser consensuadas. Mientras el gobierno de Alfonsín buscaba limitar los juicios categorizando los hechos en los marcos de la "obediencia debida", el prólogo, en cuya elaboración intervinieron comisionados que asesoraban al gobierno como Eduardo Rabossi, califica a todas las prácticas uniformada como "atroces y aberrantes", figura que debido a la reforma del Código de Justicia Militar impedía el alegato de obediencia, y exhorta a investigar a los cuadros subalternos de las Fuerzas Armadas. En igual sentido, mientras el movimiento de derechos humanos, que Jaime De Nevares, Carlos Gattinoni, Marshall Meyer, Graciela Fernández Meijide y Raúl Aragón, comisionados y secretarios de la CONADEP integraban, se enfrentaba al relato castrense sobre la "lucha antisubversiva", el prólogo valida la interpretación dictatorial sobre el "terrorismo" y hace suyo las publicaciones militares sobre el tema. ${ }^{68}$

Es decir, existen interpretaciones en el prólogo que no pueden ser subsumidas a un consenso sin fisuras. Es dable proponer, entonces, que en el prólogo confluyeron diversos intereses, lecturas y visiones sobre el pasado de violencia. No me ha sido posible reponer más detalles concretos, otras fuentes y evidencias del proceso de elaboración del prólogo. El problema es que, hasta el momento, contamos con una única versión, la publicada, y poca y contradictoria información sobre las etapas previas de una escritura que, sin dudas, fue producida en medio del vértigo de una coyuntura política candente.

En cualquier caso, la historización de las ideas que condensa el prólogo del Nunca Más así como su escritura, evidencian la intervención de diferentes actores y la mediación de complejos procesos políticos que no se agotan en la figura de Sábato, aunque salieran a la luz pública documentos concluyentes sobre su autoría. Es probable, también, que esa diversidad explique la amplia y prolongada aceptación de su lectura del pasado en la esfera pública. ${ }^{69}$

\section{Conclusiones}

En este artículo propuse pensar la genealogía de la representación que, sobre el proceso de violencia política de los años setenta, se instauró y se volvió hegemónica tras el retorno de la

${ }^{67}$ Sólo un testimonio afirma que existieron disidencias. Es el de Noemí Labrune, de la APDH, quien afirma que el Obispo Jaime De Nevares habría manifestado su desacuerdo con la proposición del prólogo de que "el terrorismo de Estado se desencadenó para enfrentar a la guerrilla", Sin embargo, las actas de la CONADEP no registran ese disenso ni tampoco fue mencionado por los comisionados entrevistados. Entrevista del autor con Noemí Labrune, fundadora de la APDH Neuquén, Buenos Aires, 10 de Septiembre de 2006.

${ }^{68}$ CONADEP, op. cit., págs. 10-11.

${ }^{69}$ Véase Kaiser, Susana, "What Happened? vs Why it Happened? Young Argentinians Remember Terror", paper presentado en la conferencia Culture and Peace: Violence, Politics, and Representation in the Americas, University of Texas at Austin, marzo de 2003. 
democracia en la Argentina en 1983. Para ello, historicé el discurso que hizo de las metáforas del infierno y el demonio, alegorías recurrentes entre intelectuales comprometidos con los derechos humanos y los sobrevivientes de las desapariciones para retratar y denunciar el universo de los centros clandestinos y la experiencia de la desaparición forzada. En estas metáforas, resonaba la impronta de la Shoá, que comenzaba a convertirse en los años ochenta en el tropos de las experiencias de violencia extrema a escala global y de la cultura de los derechos humanos, en expansión en ese mismo período, que hizo de la defensa de las víctimas de las violencias de Estado su bandera. En ambos paradigmas, las razones de los perpetradores eran desplazadas por su retrato como ejecutores de un mal, sobre víctimas absolutas, cuya dimensión eclipsaba su condición humana.

Con igual sentido, describí la emergencia del discurso de rechazo a la violencia de izquierda y derecha, entre 1973 y 1976, esquema al que adscribían Alfonsín y Sábato, pero también diversas vertientes de la izquierda. Pese a este antecedente, que retomaba equidistancias previas ante escenarios políticos polarizados, y a su mención recurrente a los "dos demonios" para aludir al proceso de violencia, Alfonsín sólo tradujo esta perspectiva en una estrategia judicial cuando la dictadura dictó la ley de "Pacificación Nacional" que eximía de persecución penal a los militares y, con importantes salvedades, a la guerrilla. En ese contexto, Alfonsín reprodujo su equidistancia pasada, rechazando ahora por igual la "impunidad y el olvido" y la "venganza", impulsando el juicio de las cúpulas guerrilleras y de las Juntas militares. En ese marco, la metáfora infernal y sus personificaciones fueron resignificadas al servicio de esa voluntad política. Alfonsín propuso una lectura novedosa del pasado de violencia. Para ello, retomó el argumento que proponía que el Estado respondió al terrorismo subversivo y propuso que dos cúpulas eran las únicas responsables de la violencia, pero postuló a un tercero, "la sociedad" y los desaparecidos, como sus víctimas. En ese contexto, la ley y la democracia, también avasalladas por las personificaciones de la violencia, evitarían la reiteración del pasado. Esta última proposición se ajustaba a una periodización que restringía a la dictadura la responsabilidad por la represión ilegal.

El prólogo de la CONADEP, comisión en la que confluyeron representantes del gobierno de Alfonsín y una fracción de los organismos de derechos humanos y personas con trayectoria en la izquierda, reproduce esta perspectiva que plantean los decretos pero, en contraste con ellos, establece la diferencia cualitativa entre el "terrorismo subversivo" y las desapariciones, categorizadas como un crimen de lesa humanidad y consagra la figura de la víctima inocente, en sintonía con el discurso de la mayoría de los organismos de derechos humanos, como objeto de las desapariciones.

En el mismo sentido, las metáforas del infierno y el demonio, a diferencia de la referencia dual de Alfonsín, son usadas por la CONADEP en el Nunca Más exclusivamente para retratar al sistema clandestino y a los perpetradores. Estas metáforas, como se dijo, trascendían a la Comisión. Lo prueba el hecho de que, también, ingresaron al corpus de su informe al incorporarse a él los testimonios de los sobrevivientes del sistema clandestino.

Aún no contamos con evidencia concluyente sobre la autoría del prólogo. Los testimonios sobre el tema están atravesados por los conflictos políticos, ciertos documentos se perdieron y otros, en archivos públicos y privados, se guardan celosamente. La emblematización del Nunca Más y su asociación con la figura de Sábato hizo de la autoría del prólogo una verdad de sentido común, ofició regularmente de vehículo para su debate y para evitar repensar las responsabilidades de la izquierda revolucionaria en el proceso político desenvuelto cuatro décadas atrás. Ellas, como las de quienes vieron en la dictadura la voluntad equidistante que pondría orden no fueron revisadas por sus autores.

Inicialmente, el prólogo fue criticado tanto por organismos de derechos humanos y por los militares. Mientras las Madres criticaron su proposición sobre su secuencia de la violencia, ex guerrilleros concordaron matizadamente con esa posición y, como las Fuerzas Armadas, 
criticaron la "equiparación" de la violencia guerrillera y estatal. Más allá del perfil de las críticas, estas evaluaciones estaban fuertemente vinculadas a las metas de los actores en los tribunales, territorio central donde se dirimió el sentido del pasado de violencia entre 1983 y 1990.

Desde mediados de los años noventa, las intervenciones sobre el prólogo tuvieron una matriz diferente. Ahora, visualizaban en su contenido el sello de los perpetradores. El infierno era entendido como obra de la voluntad de dios y de los valores occidentales y cristianos; el juicio a guerrilleros y militares como el complemento de la Doctrina de la Seguridad Nacional, y la "teoría de los dos demonios" como expresión del negacionismo de los crímenes y de la "victoria de los genocidas".

La capacidad hegemónica de la "teoría" pese a su pobreza explicativa, así como la lectura diacrónica de las discusiones que suscitó, revela más allá del boom memorialista y la realización de justicia, la existencia de un debate pendiente sobre este pasado, y sobre las prácticas y responsabilidades de los actores.

La historización aquí propuesta apostó a pensar, como fruto de distintos procesos políticos, una de las ideas más difundidas y discutidas sobre el último ciclo de violencia política en la Argentina. Aquellos años en que algunos imaginaban, al alcance de la mano, tomar el cielo por asalto y quienes lo impidieron creían personificar la voluntad de dios. Paradójicamente, o no, el anverso de esa imagen, examinada en estas páginas, resultaría la representación triunfante sobre ese tiempo.

\section{Bibliografía citada}

Actis Munú; Aldini Cristina; Gardella Liliana; Tokar Elisa y Lewin Miriam, Ese infierno. Conversaciones de cinco mujeres sobrevivientes de la ESMA, Buenos Aires, Sudamericana, 2001.

Acuña, Carlos y Smulovitz, Catalina, "Militares en la transición argentina: del gobierno a la subordinación constitucional.", en Carlos Acuña; Adriana Vaccheri., et al., Juicio, castigos y memorias, Derechos Humanos y justicia en la política Argentina, Buenos Aires, Nueva Visión, 1995, págs. 21-99.

Alfonsín Raúl, Ahora, mi propuesta política, Buenos Aires, Sudamericana-Planeta, 1983.

Anguita Eduardo; Alberto Ces; Alberto Elizalde Leal; Arturo Vivanco; Carlos Brocato; Carlos Samojedny; Fernando Dondero; Hernán Invernizzi; Hernán Schiller; Ismael Viñas; José Cuesta; María Seoane; Pablo Seydell, y Roberto Bobrow, ¿Hubo dos terrorismos? Buenos Aires, Editorial Reencuentro, 1986.

Bayer, Osvaldo, "Pequeño recordatorio para un país sin memoria", en Sosnowski Saúl (Comp.), Represión y reconstrucción de una cultura: el caso argentino, Buenos Aires, EUDEBA, 1988, págs. 203-228.

Buda, Blanca, Cuerpo I - Zona IV: (el infierno de Suarez, Mason), Buenos Aires, Contrapunto, 1988.

Campione, Daniel, "La izquierda no armada en los años setenta: tres casos, 1973-1976”, en Lida, Eugenia, Gutiérrez Crespo, Horacio y Yankelevich, Pablo (Comps.), Argentina, 1976: Estudios en torno al golpe de Estado, Buenos Aires, Fondo de Cultura Económica, 2008, págs. 85-110.

Comisión Argentina para la Defensa de los Derechos Humanos (CADHU), "Testimonios de los sobrevivientes del genocidio en la Argentina”, Barcelona, CADHU, 1979. 
Comisión Nacional sobre la Desaparición de Personas (CONADEP), Nunca Más. Informe de la Comisión Nacional sobre la Desaparición de Personas, Buenos Aires, EUDEBA, 1984.

Contepomi, Gustavo y Contepomi, Patricia, Sobrevivientes de La Perla, Córdoba, El Cid Editor, 1984.

Cortázar, Julio, "Refus de l'oubli", en Jouve, Edmond, Le refus de l'oubli. La politique de disparition forcée de personnes, París, Berger Levrault, 1982.

Cox, David, En honor a la verdad. Memorias desde el exilio de Robert Cox, Buenos Aires, Colihue, 2002.

Crenzel, Emilio, Génesis, usos y resignificaciones del Nunca Más: La memoria de las desapariciones en Argentina, Tesis de Doctorado en Ciencias Sociales, Facultad de Ciencias Sociales, Universidad de Buenos Aires, 2006.

Crenzel, Emilio, "El Nunca Más en fascículos: el infierno resignificado.", en Estudios Interdisciplinarios de América Latina y el Caribe, Volumen 17, 2, Instituto de Historia y Cultura de América Latina, Escuela de Historia, Facultad de Humanidades, Universidad de Tel Aviv, Israel 2006(b), págs. 87-106.

Crenzel, Emilio, La historia política del Nunca Más. La memoria de las desapariciones en la Argentina, Buenos Aires, Siglo XXI, 2008.

Crenzel, Emilio, "Hacia una historia de la memoria de la violencia política y los desaparecidos en la Argentina", en Allier, Eugenia y Crenzel, Emilio (Eds. y Comps), Las luchas por la memoria en América Latina.Historia reciente y violencia política, 2013, México, en prensa.

Demasi, Carlos, "Un repaso a la teoría de los dos demonios" en Marchesi, Aldo, Markarian, Vania, Rico, Alvaro, y Yaffé, Jaime (Comps.), El presente de la dictadura. Estudios y reflexiones a 30 años del golpe de Estado en Uruguay, Montevideo, Trilce, 2004, págs. 67-74.

Drucaroff, Elsa, "Por algo fue. Análisis del Prólogo a Nunca más, de Ernesto Sábato.", en Tres Galgos, Vol. 3, Buenos Aires, 2002, págs. 20-35.

Duhalde, Eduardo Luis, El Estado terrorista argentino. Quince años después una mirada crítica, Buenos Aires, EUDEBA, 1999.

Foro de Buenos Aires por la Vigencia de los Derechos Humanos, Proceso a la explotación y a la represión en Argentina, Buenos Aires, 1973.

Franco, Marina, "La "teoría de los dos demonios": consideraciones en torno a un imaginario histórico y a las memorias de la violencia en la sociedad argentina actual.", ;Atención!, Vol. 12, Instituto Austriaco para América Latina, Universidad de Viena, Austria, 2008, págs. 267-286.

Gabetta, Carlos, Todos somos subversivos, Buenos Aires, Bruguera, 1983.

Galante, Diego, El "Iuicio a las juntas militares". Derechos humanos, memoria y ciudadanía en la Argentina (1983-2011), Tesis de Doctorado en Ciencias Sociales, Facultad de Ciencias Sociales, Universidad de Buenos Aires.

Jensen, Silvina, Suspendidos de la historia/exiliados de la memoria. El caso de los argentinos desterrados en Cataluña (1976-...), Tesis de Doctorado, Universidad Autónoma de Barcelona, 2004.

Kaiser, Susana, "What Happened? vs Why it Happened? Young Argentinians Remember Terror" Paper presentado en la conferencia "Culture and Peace: Violence, Politics, and Representation in the Americas”,University of Texas at Austin, marzo de 2003.

Malamud Goti, Jaime, Terror y justicia en la Argentina. Responsabilidad y democracia después de los juicios al terrorismo de Estado, Buenos Aires, Ediciones de la Flor, 2000. 
Markarian, Vania, Left in Transformation: Uruguayan Exiles and the Latin American Human Rights Networks, 1967-1984, Nueva York, Routledge, 2005.

Nino, Carlos, Juicio al mal absoluto. Los fundamentos y la historia del juicio a las juntas del proceso, Buenos Aires, Emecé, 1997.

Nolte, Ernest, La guerra civil europea 1917-1945: Nacionalsocialismo y Bolchevismo, Fondo de Cultura Económica, 2001 [1987].

Osiel, Mark, "Ever Again: Legal Remembrance of Administrative Massacre," University of Pennsylvania Law Review, págs. 144, 463-680, 1995.

Rojkind, Inés, "La revista controversia: reflexión y polémica entre los argentinos exiliados en México.”, en Yankelevich, Pablo (Comp.), Represión y destierro. Itinerarios del exilio argentino. La Plata: Al Margen, 2004, págs. 223-251.

Secretaria de Derechos Humanos de la Nación, Prólogo a Nunca Más. Informe de la Comisión Nacional sobre la Desaparición de Personas, de Comisión Nacional sobre la Desaparición de Personas (CONADEP), Buenos Aires, EUDEBA, 2006, págs. 7-9.

Sikkink, Kathryn, “The Emergence, Evolution, and Effectiveness of the Latin American Human Rights Network", en Hershberg, Eric y Jelin, Elizabeth (eds.), Constructing Democracy: Human Rights, Citizenship and Society in Latin America, Boulder: Westview Press, 1996, págs. 59-84.

Traverso, Enzo, La historia desgarrada. Ensayo sobre Auschwitzy los intelectuales, Barcelona, Herder, 2001.

Veiga, Raúl, Las organizaciones de Derechos Humanos, Colección Biblioteca Política Argentina, nro 127, Buenos Aires, Centro Editor de América Latina, 1985.

Vezzetti, Hugo, Sobre la violencia revolucionaria. Memorias y olvidos, Buenos Aires, Siglo XXI, 2009.

Walsh, Rodolfo, "Carta Abierta de un escritor a la Junta militar", en Operación Masacre, 14ava edición, Buenos Aires, Ediciones De la Flor, 1985 [1977], págas. 205-213.

Watts, Jorge, Memorias del infierno, Peña Lillo, Buenos Aires, 2009.

Weber, Max, El político y el cientifico, Madrid, Alianza, (1997) [1919].

Wieviorka, Annette, Déportation et génocide. Entre la mémoire et l’oubli, Paris, Plon, 1992. 